\title{
Impression Management Motives, Positive Affective Tone of a Team and Organizational Citizenship Behaviors
}

Sung Won Min*

$\langle$ Contents〉
I. Introduction
IV. Results
II. Hypothesis Development
V. Discussion
III. Method

In this study, I integrate literatures of individual motives and team climate to explain employees' organizational citizenship behaviors (OCBs). Specifically, I examine the effects of impression management motives (IMM) and positive affective tone (PAT) of a team on OCBs. In addition, I apply trait activation theory to propose that PAT of a team moderates the relationship between IMM and OCBs. The results indicate that IMM and PAT have positive effects on OCBs, and the relationship between IMM and OCB is moderated by PAT.

\section{Introduction}

Over the past 30 years, organizational citizenship behavior (OCB) has received extensive attention from organizational behavior (OB) scholars. Organ (1988) originally defined OCB as "individual behavior that is discretionary, not directly or explicitly recognized by the formal reward system, and that in the aggregate promotes the effective

*Visiting professor at Dongguk University Business School 
functioning of the organization." Prior research on OCB identified the role of diverse individual characteristics, task characteristics, organizational characteristics, and leadership behaviors as antecedents to OCB (Podsakoff, MacKenzie, Paine, \& Bachrach, 2000). By definition, OCBs are considered valuable and desirable behaviors that contribute to the functioning and performance of an organization, and thus research on citizenship behaviors has been primarily focused on the factors that can increase and promote individuals' citizenship behaviors (e.g., LePine, Erez, \& Johnson, 2002; Podsakoff et al., 2000).

However, most of previous OCB research considered the roles of individual characteristics and contextual predictors in two separate literatures. Kamdar and Van Dyne (2007) suggested that it is more beneficial to integrate both literatures to predict performance of individual employees. Recent research on trait activation theory provides a basis for understanding the interactive effects of situational factors and individual traits to predict employee's behavior (Hochwarter, Witt, Treadway, \& Ferris, 2006; Kamdar \& Van Dyne, 2007; Tett \& Burnett, 2003). This approach proposes that activation of traits or abilities is likely to occur in situations that require competencies related to the trait for effective performance (Hochwarter et al, 2006). That is, whether the effects of certain trait will be prominent depends on the situation or, more specifically, whether the situation requires such trait.

Lately, scholars noticed that individual employees may utilize OCB to manage impression (e.g., Bolino, 1999; Bolino, Varela, Bande, \& Turnley, 2006; Rioux \& Penner, 2001; Yun, Takeuchi, \& Liu, 2007). That is, employees may consciously choose to engage in OCB because they have high motivation to achieve positive impressions. However, not many studies particularly examined the relationship between impression management motives (IMM), or motives that "involve a desire to maintain a positive image and to avoid creating a negative one" (Rioux \& Penner, 2001, p.1312) and OCB with a few exceptions. In this study, I intend to advance our understanding of OCB literature by investigating the effects of IMM on OCB and by examining the context that trigger or soothe the effects of IMM on OCB. Specifically, I investigate the role of positive affective tone (PAT) of a team as a moderator. 
In sum, the present study has three purposes. First, the influence of individual employee's IMM on OCB is investigated in this research. Although several scholars suggested that OCBs might stem from IMM, we do not have enough understanding yet due to lack of sufficient empirical findings. Second, I examine the role of PAT of a team on employee's OCB. Because of a dramatic increase in the use of teams in organizations (e.g., Yun, Faraj, \& Sims, 2005), team climate has become one of the critical factors that influence individual employee behaviors. There are many aspects of team climate that are important in predicting employee's work behavior. In this study, PAT of a team is considered as a relevant team climate factor that is likely to have effects on employee's OCB. Lastly, I investigate the moderating effects of PAT of a team. Applying trait activation theory, this study suggests that PAT of a team provides a context for IMM to "activate", and thus moderates the relationship between individual employee's IMM and OCB.

\section{Hypothesis Development}

\section{Impression Management Motives and Organizational Citizenship Behavior}

Most of research on OCB assumed that employee OCB is a reaction to his or her perceptions of jobs or organizations. However, there is another perspective concerning the underlying cause of employee's OCB. Penner, Midili, and Kegelmeyer (1997) argued that employees may consciously choose to engage in OCB, because such behavior satisfies their one or more motives. Rioux and Penner (2001) identified three motives that are related to individual's OCBs. They are organizational concern, prosocial value, and impression management motives (IMM). Organizational concern (OC) motives involve a desire by employees for the organization to function well and a desire for the employees to show pride in and commitment to the organization. Prosocial value (PV) motives are concerned with a need to be helpful and a desire to build positive relationships with others. Lastly, IMM involve a desire to avoid looking bad to coworkers and managers 
and to obtain desired rewards. Rioux and Penner (2001) found that OC and PV motives were related to OCB, but IMM were not. Nonetheless, the authors recommended additional studies to be conducted on IMM before reaching any conclusion regarding the effects of IMM on OCB. In fact, later Yun and his colleagues (2007) demonstrated that IMM were significantly related to OCB. Thus, while it seems promising to investigate the relationship between IMM and OCB, more studies are needed to more comprehensively explain this phenomenon.

The present study specifically focused on the effects of IMM. Researchers noted that tactics used for impression management are very similar to OCB (Bolino \& Turnley, 1999). Employees who have succeeded in creating favorable impressions are more likely to be seen as engaging in valuable behaviors, such as OCBs. Even though Rioux and Penner's (2001) study showed that IMM were not as predictive of OCB as expected, other studies still indicated that IMM have influence on OCB (Bolino, Kacmar, Turnley, \& Gilstrap, 2008). Bolino (1999) argued that when employees have high IMM, they increase their OCB especially when they are closer to their performance reviews or when they want to impress more influential individuals at work. Because OCB is commonly viewed as valuable and desirable work behaviors in organizations (e.g. Organ, 1988), employees who have high motives to be viewed more favorably by others tend to engage in more OCBs. By performing OCBs, employees can attain better images from others in the organization, thus fulfilling their high desire to look good. Therefore, I expect a positive relationship between IMM and employee OCBs.

Hypothesis 1. Employee's impression management motives are positively related to employee's organization citizenship behaviors.

\section{Positive Affective Tone of a Team and Organizational Citizenship Behavior}

Due to a dramatic increase in the use of teams in organizations, researchers have produced prolific research on how to make teams effective (e.g., Guzzo \& Dickson, 1996; Yun, Cox, Sims, \&Salam, 2007; Yun, Faraj, \& Sims, 2005). Studies showed a wide range 
of factors that may help teams and team members to be more successful. Those factors include, but not limited to, communication (Ancona \& Caldwell, 1992), leadership (Scott \& Bruce, 1994), and team climate (Agrell \& Gustafson, 1994). The present study focused on the influence that team climate, specifically positive affective tone of a team, has on employee's OCBs.

A great deal of empirical research examined the effects of climate in organizations. For instance, group OCB was found to be positively influenced by the organizational justice climate (Chen, Lam, Schaubroeck, \& Naumann, 2002). Ehrhart (2004) also found the significant relationship between procedural justice climate and unit-level OCB. D'Amato and Zijlstra (2008) reported that psychological climate affected OCB which in turn, influenced performance and burnout. In addition, researchers examined the effects of climate on outcomes such as job satisfaction (Schnake, 1983), performance (Lawler, Hall, \& Oldham, 1974), and absenteeism and turnover (Steel, Shane, \& Kennedy, 1990).

Among diverse aspects and dimensions of team climate, the present study focused on team climate which involves enthusiasm, team spirit, energy, morale, and pride. Mason and Griffin (2003) conceptualized this affective climate of a team as "positive affective tone" (PAT) of a group. Group's affective tone reflects the consistent or homogeneous affective reactions within a group, (George, 1990) and there are two independent dimensions: positive affective tone and negative affective tone (George, 1990). Mason and Griffin (2003) found that PAT of a group was negatively related to group absenteeism. They suggested that the level of PAT in the work group influences members' experience of work (George, 1990), and thus, their motivation to come to work (Steers \& Rhodes, 1978). If a team has less positive tone, members show higher level of absence behavior as a means of presenting and expressing their negative reactions to hostile climate within their team. Applying the similar notion, I examine whether PAT of a team shows a positive relationship with employee's OCBs. I argue that when team has higher PAT, team members are more likely to enjoy working in a team and with other members. They are more likely to feel supported, comfortable, and committed. These positive attitudes in turn lead to higher OCBs, as members may 
view OCBs as a means of showing their positive reactions to favorable climate within their team. High PAT will motivate employees to exhibit more extra-role behaviors, such as OCBs, which they believe will benefit their team that provides them a positive working environment. In sum, I hypothesize the positive relationship between PAT of a team and employee OCBs.

Hypothesis 2. Positive affectivity tone of a team is positively related to employee's organization citizenship behaviors.

\section{Moderating Effects of Positive Affective Tone of a Team}

In addition, I suggest a moderating role of PAT of a team on the relationship between IMM and OCBs applying trait activation theory. According to trait activation theory (Tett \& Burnett, 2003), situational factors moderate the effects of personal traits on performance. Trait activation is "the process by which individuals express their traits when presented with trait-relevant situational cues" (Tett \& Burnett, 2003, p. 502). The theory suggests that individual's ability and trait are more activated in situations where they feel the need for such ability and trait. On the contrary, powerful situations that affect individual's behavior can offset the effects of individual differences.

Researchers found support for this approach. For example, Tett and Burnett (2003) proposed that powerful reward contingencies in specific situations can mitigate the effects of personality. Hochwarter and his colleagues (2006) found that social skills predicted job performance when perceived organizational support was low. Kamdar and Van Dyne (2007) demonstrated that high quality social exchange relationships weakened the positive relationships between personality and performance. Colbert, Mount, Harter, Witt, and Barrick (2004) argued that conscientiousness was related to deviant work behavior only when the situation was perceived negatively. All these findings prove that the effects of individual characteristics are only influential when situations are not as strong to eliminate the impact of individual characteristics.

Applying trait activation theory, PAT of a team may act as a situational factor that in- 
fluences the effects of individual employee's IMM on OCB. Specifically, the relationship between IMM and OCBs will be weaker when PAT is high than when low. High PAT can be considered as a powerful situation which washes out the effects of individual employees' characteristics such as IMM on their behaviors. On the other hand, when PAT is low, the effects of individual employees' IMM become active and prominent, thus yielding higher OCBs. In short, the relationship between IMM and OCBs is stronger when PAT of a team is low than when it is high, which I hypothesize below.

Hypothesis 3. The relationship between employee's impression management motives and organization citizenship behavior is moderated by positive affective tone of a team such that the relationship is stronger when positive affective tone of a team is low than when it is high.

\section{Method}

\section{Participants and Procedures}

In order to test hypotheses, data were collected from 132 dyads of employees and their immediate managers. They were from seven organizations, and $18.9 \%$ of data were from manufacturing industry, $22.0 \%$ from financial industry, $15.2 \%$ from service industry, and 43.9\% from government agency. Two survey instruments were used in this study: one for employees and the other for their managers. Envelops which enclosed both of surveys were distributed to managers, and they were asked to finish the managerial survey themselves and provide the employee survey to one of their followers.

Among the employee sample, $77.3 \%$ of them were men and $75.0 \%$ of them were married. The education level of participants varied: $6.8 \%$ of the sample consisted of high school graduates, $7.6 \%$ had a 2-year college education, $67.4 \%$ had finished undergraduate school, and $18.2 \%$ had completed graduate school. Concerning their assigned job in the organization, $48.5 \%$ were in general management, $21.2 \%$ were in sales, $6.1 \%$ were in production, $6.8 \%$ were in $\mathrm{R} \& \mathrm{D}, 14.4 \%$ were professionals, and $3 \%$ were in other areas. Their 
average tenure in the organization was 10.0 years. The average team size was 12.6 members, and employees worked an average of 3.9 years with the team.

\section{Measures}

Focal employees were asked to provide their own IMM and PAT of a team. The manager survey contained the ratings of focal employee's organizational citizenship behavior. All of the items were measured on a seven-point Likert scale (ranging from 1 = strongly disagree to $7=$ strongly agree).

Employees rated the extent to which they possessed IMM using Rioux and Penner's (2001) measure. Among their full measure of items including PV and OC motives, I used 10 items to assess IMM. Cronbach's alpha for this scale was .84. Employees rated PAT of their team by using Mason and Griffin's (2003) 5-item measure. The reliability of this scale was .93. Managers rated the extent to which their followers performed OCBs by using Williams and Anderson (1991)'s 14-item measure of OCB. This measure is assessed by managers with a two dimensional scale (e.g., Williams \& Anderson, 1991; Ahn, Lee, $\&$ Yun, 2018). The two dimensions of OCB included are (1) organizational citizenship behavior directed toward individual (OCBI), and (2) organizational citizenship behavior directed toward organization (OCBO). Cronbach's alpha was .92 for OCBI and .86 for OCBO.

\section{Analytical Strategy}

To test Hypothesis 1 through 3, I performed hierarchical regression analyses. In step 1, IMM were included followed by PAT of a team in step 2. In step 3, the interaction term of IMM and PAT was included. In addition, I plotted the significant interaction effects. Also, I conducted simple slope analyses using the online interactive calculator for probing interactions developed by Preacher, Currna, and Bauer (2006). I investigated the relationship between IMM and employee' OCB when PAT of a team was high and when PAT of a team was low. 


\section{Results}

The means, standard deviations, and correlations are presented in $\langle$ Table 1〉. Hypothesis 1 predicted that employee's IMM would be positively related to OCB. As presented in $\langle$ Table 2$\rangle$, IMM were significantly and positively related to OCBO $(\beta=$ $.175, p<.05$, Model 2), but not to OCBI ( $\beta=.082$, n.s., Model 2). Thus, Hypothesis 1 was partially supported.

Hypothesis 2 stated that PAT of a team would be positively related to OCB. As shown in $\langle$ Table 2$\rangle$, PAT was significantly and positively related to both OCBI $(\beta=$ $.221, p<.05$, Model 2$)$ and OCBO $(\beta=.231, p<.05$, Model 2$)$. Thus, Hypothesis 2 was supported.

Hypotheses 3 proposed that employee's IMM and PAT of a team would interact to predict employee's OCB in such a way that effects of IMM would be stronger when PAT was low. As shown in $\langle$ Table 2〉, IMM and PAT of a team interacted to predict OCBO ( $\beta=-2.713, p<.01$, Model 3$)$, but not OCBI $(\beta=-1.294$, n.s., Model 3). The interaction term explained a significant amount of the variance in OCBO beyond that accounted for by the main effects $(\Delta \mathrm{F}=9.385, p<.01$, Model 3). To examine this interaction, the figure was created by following the procedure suggested by Aiken and West (1991).

Consistent with the expectation, 〈Figure 1〉 shows that when PAT of a team was low,

$\langle$ Table 1〉 Descriptive Statistics of the Variables

\begin{tabular}{|c|c|c|c|c|c|c|}
\hline Variables & Mean & $\mathrm{SD}$ & 1 & 2 & 3 & 4 \\
\hline 1. $\mathrm{IMM}^{\mathrm{a}}$ & 5.47 & .68 & $(.84)$ & & & \\
\hline 2. PAT $^{b}$ & 5.07 & .98 & $.375^{* *}$ & $(.93)$ & & \\
\hline $3 . \mathrm{OCBI}^{\mathrm{c}}$ & 4.70 & .99 & .082 & .220 & $(.92)$ & \\
\hline 4. $\mathrm{OCBO}^{\mathrm{d}}$ & 5.22 & .90 & .175 & .264 & $.597 * *$ & $(.86)$ \\
\hline
\end{tabular}

Note. $\mathrm{N}=132$. Reliabilities are on the diagonal in parentheses. $* *$ Correlation is significant at the 0.01 level (2-tailed). * Correlation is significant at the 0.05 level (2-tailed). ${ }^{\text {a }}$ IMM=Impression management motives, ${ }^{\mathrm{b}}$ PAT $=$ Positive affective tone of a team, ${ }^{\mathrm{c}} \mathrm{OCBI}=$ Organizational citizenship behavior directed at individuals, ${ }^{\mathrm{d}} \mathrm{OCBO}=$ Organization citizenship behavior directed at organization 
$\langle$ Table 2〉 Regression Results on Organizational Citizenship Behaviors

\begin{tabular}{|c|c|c|c|c|c|c|}
\hline \multirow{2}{*}{ Variable } & \multicolumn{3}{|c|}{ OCBI } & \multicolumn{3}{|c|}{ OCBO } \\
\hline & Model1 & Model2 & Model3 & Model1 & Model2 & Model3 \\
\hline \multicolumn{7}{|l|}{ Step1: Main effects } \\
\hline Impression management motives & .082 & -.001 & -.590 & $.175^{*}$ & .088 & $1.328 * *$ \\
\hline \multicolumn{7}{|l|}{ Step2: Main effects } \\
\hline Positive affective tone of a team & & $.221^{*}$ & $-1.165+$ & & $.231^{*}$ & $2.211 * * *$ \\
\hline \multicolumn{7}{|l|}{ Step3: Interaction } \\
\hline $\mathrm{IMM}^{\mathrm{a}} *$ PAT $^{\mathrm{b}}$ & & & -1.294 & & & $-2.713 * *$ \\
\hline Overall $\mathrm{F}$ & .880 & $-3.294 *$ & $-2.866^{*}$ & $4.114 *$ & $5.342^{* * *}$ & $-6.922 * * *$ \\
\hline $\mathrm{R}^{2}$ & .007 & -.049 & -.063 & .031 & .076 & -.140 \\
\hline F change & & $-5.676^{*}$ & -1.961 & & $6.400 *$ & $-9.385^{* *}$ \\
\hline $\mathrm{R}^{2}$ change & & $-.042 *$ & -.014 & & $.046^{* *}$ & $-.063 * *$ \\
\hline
\end{tabular}

Note. $\mathrm{N}=132$. Entries are standardized regression coefficients. When control variables (age, gender, education level, organization tenure, job category, employment type, tenure with the team, team size) are included, results are stable.

${ }^{\mathrm{a}}$ IMM=Impression management motives, ${ }^{\mathrm{b}} \mathrm{PAT}=$ Positive affective tone of a team.

${ }^{\dagger} \mathrm{p} \leq .1, * \mathrm{p} \leq .05, * * \mathrm{p} \leq .01, * * * \mathrm{p} \leq .001$ (two-tailed)

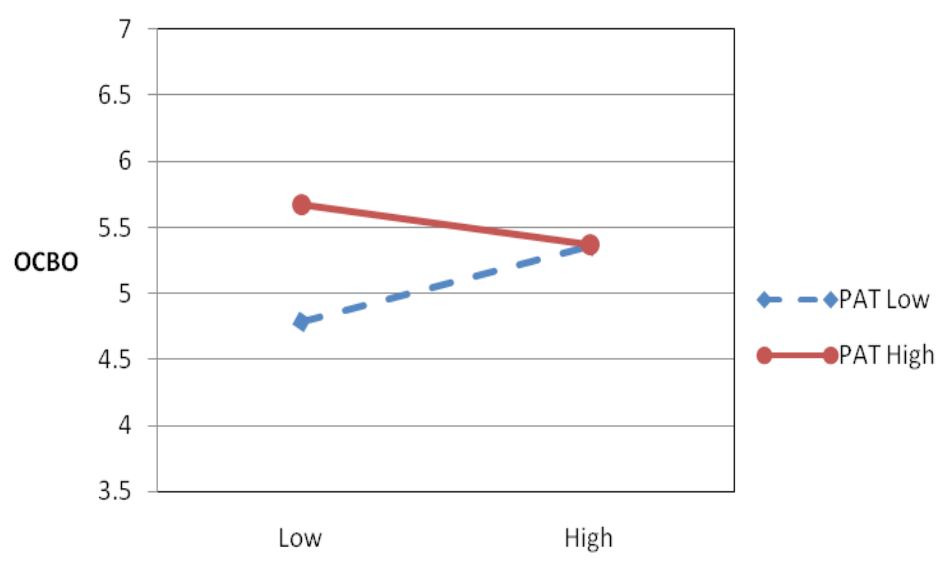

Impression Management Motives

$<$ Figure $1>$ Interaction of IMM and PAT on OCBO 
OCBO was more likely to be affected by employee's IMM than when PAT of a team was high. Simple slope analyses indicated that the positive relationship between IMM and OCBO was significant when PAT of a team was low $(\beta=.428, p<.01)$, but the relationship was not significant when PAT of a team was high $(\beta=-.220$, n. s.). These results partially supported Hypothesis 3 .

\section{Discussion}

As extensive amount of previous research on OCB implies, OCB is one of the most critical work outcomes that support organizations to be successful in today's competitive environment. To date, researchers identified diverse factors that either increase or decrease employee's OCB. However, not many of the studies examined both individual and situational factors simultaneously. Lately, researchers are emphasizing the benefits of demonstrating interactive effects of individual characteristics and situational factors (Colbert et al., 2004; Hochwarter et al., 2006; Kamdar \& Van Dyne, 2007). This study contributes to this stream of research by integrating individual and contextual predictors of OCB.

First, as an individual predictor, I examined employee's IMM. The results of this study showed that employee's IMM had direct effects on employee's OCB. Specifically, IMM were positively related to OCBO, but not significantly related to OCBI. My findings differ from Rioux and Penner (2001)'s findings that showed that IMM were not significantly related to OCB, except for Sportsmanship dimension. However, the results of the present study were consistent with Yun and his colleagues' (2007) study where they found that self-enhancement motive was significantly and positively related to OCBO but not to OCBI. These results imply that impression management can be beneficial for the functioning of the organization to some degree, but in limited range. This study's results indicated that employees who have high IMM are more likely to perform behaviors such as OCBO, which produces positive consequences for the organization. As previous studies indicate inconsistent findings, future research needs to 
investigate this complex issue further.

My results demonstrated that those with high IMM were more inclined to perform OCBO than OCBI. These findings implied that OCBO may not be purely altruistic but involve more instrumental motives. On the other hand, as OCBI is directly related to interpersonal relationships and interactions, it may require more of sincere efforts than OCBO, and thus employees may not use OCBI as just a tactic to enhance self-image. These findings imply that the effects of OCBI and OCBO on the functioning and the performance of an organization may be different. That is, if OCBO stems from impression management motive (or instrumental motive) but OCBI derives from more altruistic motive, the latter may have larger impact on organizational performance and functioning than the former in the long run. Future research needs to address this issue further as it seems clear that the mechanisms through OCBI and OCBO are triggered are distinct, and underlying motives function in disparate directions.

As a contextual predictor of OCB, I included PAT of a team, which was found significantly and positively related to employee's OCB. The findings showed that PAT of a team is one of critical factors in predicting work behaviors of employees in the organization. As employees perceive their team climate to be more positive, employees become more willing to go extra mile in the workplace. They behave positively and beneficially as a reaction to their positive, favorable working environment. One notable finding was that PAT of a team was positively related to both OCBI and OCBO whereas IMM was only related to OCBO. That is, when an employee perceives his or her team to have positive affective climate, he or she acts prosocially not only towards the organization or team itself, but also towards other members in it. As other dimensions of climate are found influential in organizations (e.g. Chen et al., 2002; D'Amato \& Zijlstra, 2008; Ehrhart, 2004; Lawler et al., 1974; Schnake, 1983; Steel et al., 1990), we can stretch our interest and consider affective tone of a team as a strong predictor of employee's OCBs.

In an attempt to examine interactive effects of aforementioned individual and contextual predictors of $\mathrm{OCBs}$, I applied trait activation theory. Trait activation theory suggests that individual's traits are more activated in particular situations, where such 
traits are needed (Tett \& Burnett, 2003). In other words, when there is a powerful situation that has strong effects on certain behaviors, the effects of individual characteristics on such behaviors may be masked or eliminated. Consistent with trait activation theory, I argued that effects of individual IMM would be stronger when PAT of a team is low than when it is high. That is, it is only when PAT of a team, which has strong effects on OCB, is not present, that the effects of IMM on OCB becomes significant. The results of this study demonstrated that perceptions of PAT of a team moderated the relationship between IMM and OCB such that the effects of IMM were stronger when employees perceived PAT of their team to be low. That is, employees with high IMM would more likely to exhibit higher OCBs, when positive team climate is absent. The results of this study supported trait activation theory and also further proved that the theory can be applied not only to personality traits but also to other individual characteristics such as motives.

The findings on PAT can provide practical implications to managers and organizations. In a situation in which a manager has an employee who lacks certain motives or other characteristics that can induce positive behaviors, my findings suggest that creating positive team climate would be an effective option for enhancing employee's positive behaviors or performance. In addition, organizations may need to provide resources and support for managers to create high PAT of a team. Future research needs to examine the role of manager in developing PAT of a team. In addition, due to a recent trend toward flat organizations, coworker becomes a critical source of influence at workplace (Chiaburu \& Harrison, 2008). Thus, coworkers are likely to play a critical role in developing a team's PAT. Future research needs to address this issue and explore the effects of coworkers and relationships with them on the overall team's affective tone.

There are, of course, few limitations of this study. First, this study used a cross-sectional design and collected data at one point in time. Therefore, we cannot be sure about the causal direction of relationships. Although the results are consistent with the theoretical predictions and conceptualization, longitudinal study designs need to be pursued to draw firmer conclusions in this regard.

Another limitation lies in the scale of IMM used in this study. Rioux and Penner (2001) 
noticed the limitation of their IMM measure in that it probably failed to distinguish between impression management that is "acquisitive" (i.e. intended to get something from others) and that which is "self-protective" (i.e. intended to avoid negative evaluations; Gangstead \& Snyder, 2000). These two aspects of impression management need to be viewed and emphasized separately. Therefore, in future research, employee's motives to enhance self-image as well as to avoid looking negatively should be considered separately to more accurately explain the role of employee's IMM.

Whereas this study only involved individual employees' motives, specifically IMM, for engaging in $\mathrm{OCB}$, further studies can examine how attributions others make of employee's motives have influence. For instance, Halbesleben, Bowler, Bolino, and Turnley (2010) found that perceived IMM motive may lead to negative supervisory ratings. When others perceive employee's motive for exhibiting OCB stems from his or her motive to develop positive self-image, such OCB may not be viewed as valuable as other motive-driven OCBs. Whereas there is a controversy on whether IMM-driven OCB is still beneficial or not, it seems clear that more research needs to explore and address this complex issue.

Lastly, this study only focused on the limited variables of individual characteristics and contextual factors. For instance, other individual traits such as motives other than IMM and situational variables such as organizational politics or leadership styles can be potential antecedents of OCBs as many of other studies have been emphasizing. More importantly, fruitful research area that examines joint influence of more diverse, unique individual and contextual predictors of work behaviors is still waiting to be unveiled.

Despite the limitations, this study contributes to enhancing our understanding of employee citizenship behaviors. The findings demonstrated that individual employee's OCB may stem from instrumental motives, such as IMM. In addition, the results of this study showed the importance of positive team climate in the organization. Furthermore, this research showed interactive effects of motives and contextual variable by applying trait activation theory. Introducing influential individual and situational factors simultaneously, this study provides a way to promote valuable employee work behaviors, and opens up a new venue for further investigation. 


\section{References}

Agrell, A., \& Gustafson, R. (1994). The team climate inventory (TCI) and group innovation: A psychometric test on a Swedish sample of work groups. Journal of Occupational and Organizational Psychology, 67, 143-151.

Ahn, J., Lee, S., \& Yun, S. (2018). Leaders' core self-evaluation, ethical leadership, and employees' job performance: The moderating role of employees' exchange ideology. Journal of Business Ethics, 148, 457-470.

Aiken, L.S., \& West, S. G. (1991). Multiple regression: Testing and interpreting interactions. Newbury Park, CA: Sage.

Ancona, D. G., \& Caldwell, D. F. (1992). Bridging the boundary: External activity and performance in organizational teams. Administrative Science Quarterly, 37, $634-665$

Bolino, M. C. (1999). Citizenship and impression management: Good soldiers or good actors? Academy of Management Review, 24, 82-98.

Bolino, M. C., Kacmar, K. M., Turnley, W. H., \& Gilstrap, J. B. (2008). A multi-level review of impression management motives and behaviors. Journal of Management, 34, 1080-1109.

Bolino, M. C., \& Turnley, W. H. (1999). Measuring impression management in organizations, a scale development based on the Jones and Pittman taxonomy. Organizational Research Methods, 2, 187-206.

Bolino, M. C., Varela, J. A., Bande, B., \& Turnley, W. H. (2006). The impact of impression management tactics on supervisor ratings of organizational citizenship behavior. Journal of Organizational Behavior, 27, 281-297.

Chen, X. P., Lam, S. S. K., Naumann, S. E., \& Schaubroeck, J. M. (2005). Group citizenship behavior: Conceptualization and preliminary tests of its antecedents and consequences. Management \& Organization Review, 1, 273-300.

Chiaburu, D. S., \& Harrison, D. A. (2008). Do peers make the place? Conceptual synthesis and meta-analysis of coworker effects on perceptions, attitudes, OCBs, and performance. Journal of Applied Psychology, 93, 1082-1103. 
Colbert, A. E., Mount, M. K., Harter, J. K., Witt, L. A., \& Barrick, M. R. (2004). Interactive effects of personality and perceptions of the work situation on workplace deviance. Journal of Applied Psychology, 89, 599-609.

D’Amato, A., \& Zijlstra, F. R. H. (2008). Psychological climate and individual factors as antecedents of work outcomes. European Journal of Work and Organizational Psychology, 17, 33-54.

Ehrhart, M. C. (2004). Leadership and procedural justice climate as antecedents of unitlevel organizational citizenship behavior. Personnel Psychology, 57, 61-94.

Gangstead, S. W., \& Snyder, M. (2000). Self-monitoring: Appraisal and reappraisal. Psychological Bulletin, 126, 530-555.

George, J. M. (1990). Personality, affect, and behavior in groups. Journal of Applied Psychology, 75, 107-116.

Guzzo, R. A., \& Dickson, M. W. (1996). Teams in organizations: Recent research on performance and effectiveness. Annual Review of Psychology, 47, 307-338.

Halbesleben, J. R., Bowler, W. M. Bolino, M. C., \& Turnley, W. H. (2010). Organizational concern, prosocial values, or impression management? How supervisors attribute motives to organizational citizenship behavior. Journal of Applied Social Psychology, 40, 1450-1489.

Hochwarter, W. A., Witt, L. A., Treadway, D. C., \& Ferris, G. R. (2006). The interaction of social skill and organizational support on job performance. Journal of Applied Psychology, 91, 482-489.

Kamdar, D., \& Van Dyne, L. (2007). The joint effects of personality and workplace social exchange relationships in predicting task performance and citizenship performance. Journal of Applied Psychology, 92, 1286-1298.

Lawler, E. E., Hall, D. T., \& Oldham, G. R. (1974). Organizational climate: Relationship to organizational structure, process and performance. Organizational Behavior \& Human Decision Processes, 11, 139-155.

LePine, J. A., Erez, A., \& Johnson, D. E. (2002). The nature and dimensionality of organizational citizenship behavior: A critical review and meta-analysis. Journal of Applied Psychology, 87, 52-65. 
Mason, C. M., \& Griffin, M. A. (2003). Group absenteeism and positive affective tone: A longitudinal study. Journal of Organizational Behavior, 24, 667-687.

Organ, D. W. (1988). Organizational citizenship behavior: The good soldier syndrome. Lexington, MA: Lexington Books.

Penner, L. A., Midili, A. R., \& Kegelmeyer, J. (1997). Beyond the job attitudes: A personality and social psychology perspective on the causes of organizational citizenship behavior. Human Performance, 10, 111-132.

Podsakoff, P. M., MacKenzie, S. B., Paine, J. B., \& Bachrach, D. G. (2000). Organizational citizenship behaviors: A critical review of the theoretical and empirical literature and suggestions for future research. Journal of Management, 26, 513-563.

Preacher, K. J., Curran, P. J., \& Bauer, D. J. (2006). Computational tools for probing interactions in multiple linear regression, multilevel modeling, and latent curve analysis. Journal of Educational and Behavioral Statistics, 31, 437-448.

Rioux, S. M., \& Penner, L. A. (2001). The causes of organizational citizenship behavior: A motivational analysis. Journal of Applied Psychology, 86, 1306-1314.

Schnake, M. E. (1983). An empirical assessment of the effects of affective response in the measurement of organizational climate. Personnel Psychology, 36, 791-807.

Scott, S. G., \& Bruce, R. A. (1994). Determinants of innovative behavior: A path model of individual innovation in the workplace. Academy of Management Journal, 37, 580-607.

Steel, R. P., Shane, G. S., \& Kennedy, K. A. (1990). Effects of social system factors on absenteeism, turnover, and job performance. Journal of Business and Psychology, 4, 423-430.

Steers, R. M., \& Rhodes, S. R. (1978). Major influences on employee attendance: A process model. Journal of Applied Psychology, 63, 391-407.

Tett, R. P., \& Burnett, D. D. (2003). A personality trait-based interactionist model of job performance. Journal of Applied Psychology, 88, 500-517.

Williams, L. J., \& Anderson, S. E. (1991). Job satisfaction and organizational commitment as predictors of organizational citizenship and in-role behaviors.

Journal of Management, 17, 601-617. 
Yun, S., Cox, J., Sims, H., Jr., \& Salam, S. (2007). Leadership and teamwork: The effects of leadership and job satisfaction on team citizenship. International Journal of Leadership Studies, 2, 171-193.

Yun, S., Faraj, S., \& Sims, H. P., Jr. (2005). Contingent leadership and effectiveness of trauma resuscitation teams. Journal of Applied Psychology, 90, 1288-1296

Yun, S., Takeuchi, R., \& Liu, W. (2007). Employee self-enhancement motives and job performance behaviors: Investigating the moderating effects of employee role ambiguity and managerial perceptions of employee commitment. Journal of Applied Psychology, 92, 745-756. 


\title{
인상관리 동기와 팀의 분위기가 종업원 조직시민행동에 미치는 영향에 대한 연구
}

\author{
민 성 원*
}

\section{요 약}

조직행동론에서 종업원 조직시민행동에 대한 연구는 꾸준히 진행되어 왔으며, 많은 연구자들 이 조직시민행동의 다양한 선행변수들을 밝혀냈다. 그러나 대부분의 기존 연구는 개인의 특성 또 는 상황적 변수들을 분리하여 살펴보아 연구의 폭이 다소 제한적이라는 한계가 있다. 본 연구에 서는 종업원 개인의 특성인 동기와 상황적 변수인 팀의 분위기를 통합하여 종업원 조직시민행동 을 설명하고자 한다. 먼저, 종업원의 인상관리 동기가 조직시민행동에 미치는 영향을 살펴본다. 그동안 종업원 조직시민행동을 유발하는 동기 중 가장 상반되는 결과를 보여온 인상관리 동기를 심층적으로 연구해보고자 한다. 이어서 팀의 긍정적인 정서적 분위기가 종업원 조직시민행동에 미치는 영향을 살펴본다. 조직 내 팀의 사용이 급격하게 증가함에 따라 종업원 개인의 행동에 대 한 팀의 영향력을 함께 살펴보고자 함이다. 마지막으로, 팀의 분위기의 조절효과를 알아본다. 특 성활성화 이론을 적용하여, 팀의 분위기가 언제 종업원의 인상관리 동기를 “활성화”하는지, 즉 종 업원의 인상관리 동기가 조직시민행동에 갖는 효과가 팀의 분위기에 따라 어떻게 변화하는지를 살펴본다. 이처럼 본 연구는 종업원 조직시민행동에 미치는 중요한 개인적, 상황적 요소를 함께 살펴봄으로써, 가치 있는 종업원 행동을 촉진시키는 방법을 모색하고, 앞으로의 새로운 연구방향 을 제시하고자 한다.

\footnotetext{
*동국대학교 경영대학 강의초빙교수
} 